\title{
Activism in Practice: The Influence of a Rural School Leader's Beliefs and Practices in Disrupting Historical Patterns of Underachievement in Traditionally Marginalized Students
}

\author{
Kristina A. Hesbol \\ University of Denver \\ kristina.hesbol@du.edu
Jennifer Sparkman Bartee
University of Denver
jen.bartee@du.edu \\ Fayaz Amiri \\ University of Denver \\ fayaz.amiri@du.edu
}

\begin{abstract}
Despite the fact that rural communities across the United States are rapidly diversifying (Fusarelli \& Militello, 2012), little research has examined the beliefs and practices of successful rural educational leaders, specifically in high poverty schools and districts where traditionally marginalized students demonstrate improving learning outcomes. The purpose of this study was to examine the beliefs and practices of a rural educational leader whose school or district met established study criteria for a high poverty, high performing school, in which traditionally marginalized students demonstrate increasingly productive learning outcomes. Interviews with the leader were conducted, and the data were coded and analyzed using a constant comparative method (Lincoln \& Guba, 1985).

The following research question guided the study:

What impact do the beliefs and practices of a rural school district leader have on the learning outcomes of traditionally marginalized students in the Rocky Mountain West?

The findings from this study contribute to the paucity of research on culturally responsive rural superintendent-principals. Identifying the rural leader's beliefs and practices provides support for educational leaders who serve in that uniquely rural dual role, about which very little has been written. It informs leadership preparation programs, graduate students, researchers, and policy makers about the need for nuanced culturally responsive training for rural educational leaders.
\end{abstract}

KEYWORDS: rural superintendent-principal, culturally responsive leadership, relational leadership

In this article, we present a study that reports how the beliefs and practices of a rural superintendent-principal influence the increased learning outcomes of traditionally marginalized students. At the 2017 Convening of the Carnegie Project on the Education Doctorate (CPED), Executive Director Jill Perry (2018) reminded members that CPED's Design Concepts provide a foundational platform from which to revolutionize the preparation of doctoral graduates to improve the field - as Lee Shulman suggests, "to think, to perform, and to act with integrity" (Shulman, 2005, p. 52). Inquiry as practice pushes our capacity to innovate, dismantling oppressive systems and leading improvement for every student. The case study that follows was conducted by a graduate student-professor team and is used in our Ed.D. program to expand the thinking of our doctoral students, most of whom have worked only in urban schools. It illuminates the need for innovation and activism as a rural leader in order to lead equitable improvement in the local school, district, and community, and provides real-world "fieldwork experience" for Ed.D. programs with a broader lens through which to develop culturally responsive school and district leadership.
New articles in this journal are licensed under a Creative Commons Attribution 4.0 United States License.

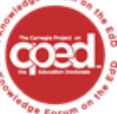

This journal is supported by the Carnegie Project on the Education Doctorate: A Knowledge Forum on the EdD (CPED) cpedinitiative.org 
According to a 2019 report from The Rural School and Community Trust, 9.3 million students are enrolled in American rural public schools - nearly one out of every seven students in the country (Showalter et al, 2019). Rural communities across the US are rapidly diversifying racially, culturally, and linguistically (Fusarelli \& Militello, 2012; Pohl, 2017), and one in six of those students lives below the poverty line. Despite such data, little research has been conducted to examine the beliefs and practices of successful rural educational leaders - specifically those in whose schools traditionally marginalized students demonstrate improving learning outcomes. As a result, successful rural educational leaders are left to advocate largely on their own to access professional development to meet the changing needs of students, their schools, and their communities. We see this as a civil rights issue.

\section{PURPOSE}

The purpose of this qualitative case study was to examine the influence of the beliefs and practices of a rural school leader to disrupt low expectations for student learning, evidenced by achievement gaps, including the nuanced, place-based challenges that are unique to rural contexts. The study focused on rural students who identify as emerging bilingual learners, as Hispanic or Native American, and/or as economically under-resourced, whose learning outcomes in math meet or exceed state standards. The research question that guided this study is:

What impact do the beliefs and practices of a rural school district leader have on the learning outcomes of traditionally marginalized students in the district in the Rocky Mountain West?

\section{STATEMENT OF THE PROBLEM}

Rural educators at the building and district level (sometimes the same person, as in the case of this study's superintendent-principal) are called to re-imagine their leadership beliefs and practices in order to equitably meet the needs of their demographically changing communities. Few leadership preparation programs are designed specifically to develop and equity-focused, inclusive, and innovative rural educational leaders. A focus on equity requires a purposeful redistribution of power and resources to repair the sociopolitical and moral "educational debt" (Ladson-Billings, 2006) owed to historically marginalized students (Galloway \& Ishimaru, 2015; Brayboy, Castagno, \& Maughan, 2007; Darling-Hammond, 2010). This call for activism needs to be addressed by leadership preparation and professional development programs, providing a deeper and broader perspective on a continuum of nuanced rural educational contexts.

Despite a relentless national focus on the effect of the achievement gap on urban students, relatively limited research has been conducted on leaders of schools and districts in rural communities and their influence on student learning. $68 \%$ of American rural schools report significant achievement gaps (Zhang, 2008; Barrett, Cowen, Toma, \& Troske, 2015), but few rural leaders report that they know how to eliminate them. To provide the important data needed to help improve learning outcomes for every rural student, studies must investigate the critical leadership beliefs and practices of those successful educational leaders who improve schools (Leithwood, Louis, Anderson, \& Wahlstrom, 2004), including culturally responsive leadership behaviors (Khalifa, Gooden, \& Davis, 2016). While the school reform literature includes numerous studies linking student learning with such strategies as progress monitoring (Harris, 2013; Bernhardt, 2013) and differentiated instruction (Hallinger, Heck, \& Murphy, 2014; Valiandes, 2015), there is a paucity of studies that focus on the leader's beliefs and practices, specifically in rural schools. Since $1980,95 \%$ of rural counties in the Rocky Mountain West have seen growth in minority populations (see Figure 1). In $40 \%$ of these counties, overall population decrease slowed or reversed due to the growth of minority populations (Pohl, 2017). These data support the need to examine rural educational leaders' beliefs and practices and their influence on student learning outcomes, particularly as their students diversify racially, culturally, linguistically, and economically. 


\section{Minority Trends in the Rural West, 1980 - 2015}

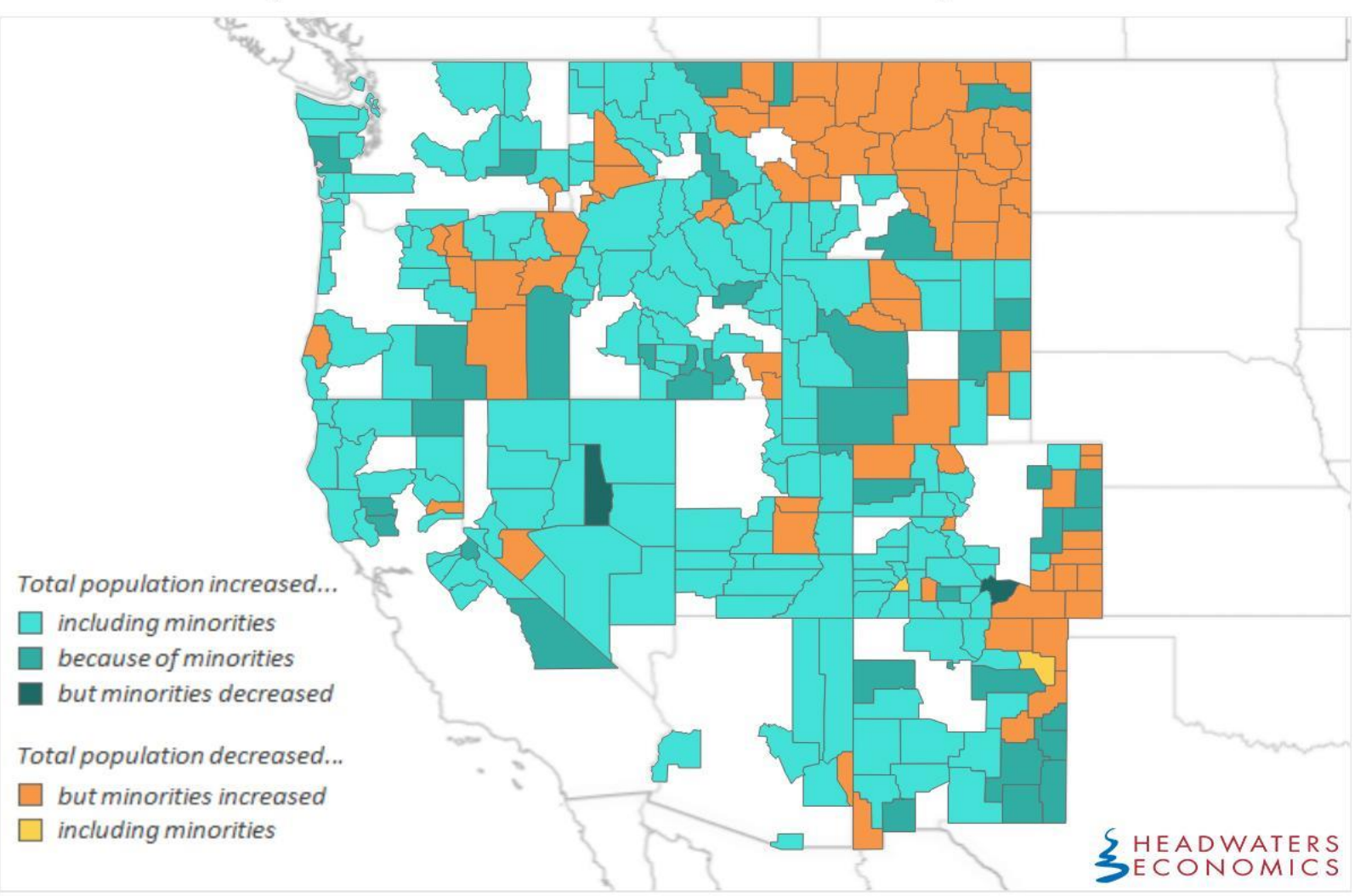

Figure 1. Minority Trends in the Rural West, 1980-2015

Equity-focused leaders identify and challenge practices that marginalize students, and create schools that adeptly respond to the educational, social, and cultural needs of every student and their communities (Khalifa, 2018). They interrogate barriers to equitable practice, and question narratives that justify exclusionary practices that reproduce hegemony. Often, rural leaders are "expected to act within accepted dominant values and norms of the community, in effect charged with upholding the traditional power structures that can create inequity" (McHenry-Sorber \& Provinzano, 2017, p. 608).

Research on schools whose historically marginalized students demonstrate increasingly successful learning outcomes indicates that their principals actively reform the school curriculum to become more culturally responsive (Sleeter, 2012), and move their teachers from a defensive resistance attitude (Jacobs, Boardman, Potvin, \& Wang, 2018) to a sense of pride and empowerment, resulting from their students' success (Balkar, 2015). Eliminating deficit mindsets and supporting diverse students' funds of knowledge and community cultural wealth (Kiyama, Rios-Aguilar \& Sarubbi, 2018; Yosso, 2005) are additional requisite leadership responsibilities to guide schools and districts that genuinely welcome all students and families. As communities in the rural West continue to diversify, it will be particularly critical for leadership to be prepared to be culturally responsive (Khalifa, 2018) to meet students' changing needs.
There is limited description in the scholarly literature of a rural principal's daily practice, focused through a lens of school improvement and grounded in equity and justice (Hesbol, 2020). Data from a seven-state study (Salazar, 2007) indicate that rural principals need more professional development to meet changing role expectations, exacerbated by rapidly increasing diversity and poverty. Such training includes culturally responsive leadership behaviors (Khalifa, Gooden, \& Davis, 2016). Pounder, Reutzug and Young (2002) stressed that training for school leaders in all contexts must prepare the to address "issues of demographic diversity, poverty, racism, ethnocentrism, language differences, homophobia, sexism, and their intersections within educational policies and practices" (p. 270). The most impactful areas of influence on student learning outcomes identified in Leithwood, Louis, Anderson and Wahlstrom's (2004) formative study are the principal's focused work to:

- $\quad$ set direction for the school

- develop faculty

- redesign the organization

- manage the instructional program
New articles in this journal are licensed under a Creative Commons Attribution 4.0 United States License.

ULS

This journal is published by the University Library System of the University of Pittsburgh as part of its D-Scribe Digital Publishing Program and is cosponsored by the University of Pittsburgh Press.

This journal is supported by the Carnegie Project on the Education Doctorate: A Knowledge Forum on the EdD (CPED) cpedinitiative.org 
Such leaders create an increased urgency for change; they focus their work on such issues as disrupting inequity and white privilege (Theoharis \& Causton-Theoharis, 2008; Skrla, McKenzie, \& Scheurich, 2009). Very little research has examined an educational leader unique to rural contexts, the superintendent-principal. The findings of one study (Hesbol, 2005) confirm consistent role conflict inherent in this dual role, due to the diffused responsibilities to multiple constituent groups with whom a superintendent-principal works. The superintendent/principal position typically exists as a result of the difficult financial circumstances facing small rural school districts. Selecting a dual role administrator allows rural school districts to significantly reduce their administrative costs. Because of divergent expectations by their board, faculty, and the state, these leaders consistently report greater focus on fiscal management than on instructional leadership or professional development for their teachers or themselves (Curry, 2016).

\section{RESEARCH DESIGN}

Most of the literature on culturally responsive school leadership has been situated within urban contexts. The Culturally Responsive School Leadership Framework (Khalifa, Gooden, and Davis, 2018) (see Table 1) emerged from an extensive review of the literature on culturally responsive leadership. We used it as the conceptual framework for this study.

In the study site state, the department of education designated 148 of the 196 school districts as rural and compiled a database of all "Rural and Small Rural Districts." According to this taxonomy, a rural district is located no less than 25 miles from an urban cluster (Geverdt, 2015). A small rural district has less than 1,000 students with the same locality criterion; 15 districts in this state have less than 100 registered students.

\section{Site Selection}

We set the following criteria parameters to include a school for consideration in this study:

- It aligned with the National Center for Education Statistics (Geverdt, 2015) definition of rural on the NCES urbanicity scale;
- $\quad$ Students scored in the top $50 \%$ ile overall on the annual state math performance measure;

- The school's achievement gap in math was less than 15 points between non-white and white students, emerging bilingual students and native Englishspeaking students, and between economically underresourced students and their peers. Math was selected as a content area criterion based on our assumption that math likely impacts the learning outcomes of emerging bilingual students less than in language-based content areas; and

- No less than 50 percent of students at the elementary level, 40 percent of students at the middle school level, or 35 percent of students at the high school level qualified for Free and Reduced Lunch.

The initial scans identified ten schools in the state that satisfied all four of these criteria - six elementary, three middle, and one high school. We contacted each school's principal, inviting each to participate in this study. Only two schools responded, despite sending a second invitation to each of the ten principals. One principal was excluded from this study following an initial interview, after we learned that she was not focused on inclusive practices to improve learning outcomes for every student. As a result, we invited Principal Mark Taylor to participate in the study (names of all persons and places in this study are pseudonyms). Mr. Taylor serves as the superintendent-principal at Great Bend School District, which has a student enrollment of 197 students in grades K-12. There were neither enough black nor white students in the district $(n<16)$ to assess discrepant score gaps including these students; otherwise, the district met all criteria. It is a rural and remote district whose traditionally marginalized students show increasingly productive learning outcomes. Great Bend received a "Meets Expectations" rating in 2019, the second highest of five set by the state board of education.

$20 \%$ of students in the Great Bend School District identify as emerging bilingual ( $4 \%$ more than the state average). $78 \%$ of the students identify as Hispanic, compared to the state average of $47 \%$. $67 \%$ of the district's students are eligible for Free and Reduced Lunch, compared to $41 \%$ of the students in the state who qualify.

A descriptive case study (Stake, 1995; Yin, 2017) was used to collect and interpret data about the beliefs and practices of this principal. 


\title{
Culturally Responsive School Leadership Framework
}

\author{
Muhammad Khalifa, University of Minnesota \\ Mark Anthony Gooden, University of Texas \\ James Earl Davis, Temple University
}

\begin{tabular}{|c|c|}
\hline Critically Self-Reflects on Leadership Behaviors & Develops Culturally Responsive Teachers \\
\hline $\begin{array}{l}\text { - Is committed to continuous learning of cultural } \\
\text { knowledge and contexts (Gardiner \& Enomoto, 2006) } \\
\text { - Displays a critical consciousness on practice in and out } \\
\text { of school; displays self-reflection (Gooden \& Dantley, 2012; } \\
\text { Johnson, 2006) } \\
\text { - Uses school data and indicants to measure CRSL (Skrla, } \\
\text { Scheurich, Garcia, \& Nolly, 2004) } \\
\text { Uses parent/community voices to measure cultural } \\
\text { responsiveness in schools (Ishimaru, 2013; Smyth, 2006) } \\
\text { - Challenges Whiteness and hegemonic epistemologies in } \\
\text { school (Theoharis \& Haddix, 2011) } \\
\text { - Using equity audits to measure student inclusiveness, } \\
\text { policy, and practice (Skrla et al., 2004) } \\
\text { Leading with courage (Khalifa, 2011; Nee-Benham, Maenette, \& } \\
\text { Cooper, 198s) } \\
\text { Is a transformative leader for social justice and } \\
\text { inclusion (Alston, 2005; Gooden, 2005; Gooden \& O'Doherty, 2015; } \\
\text { Shields, 2010) }\end{array}$ & 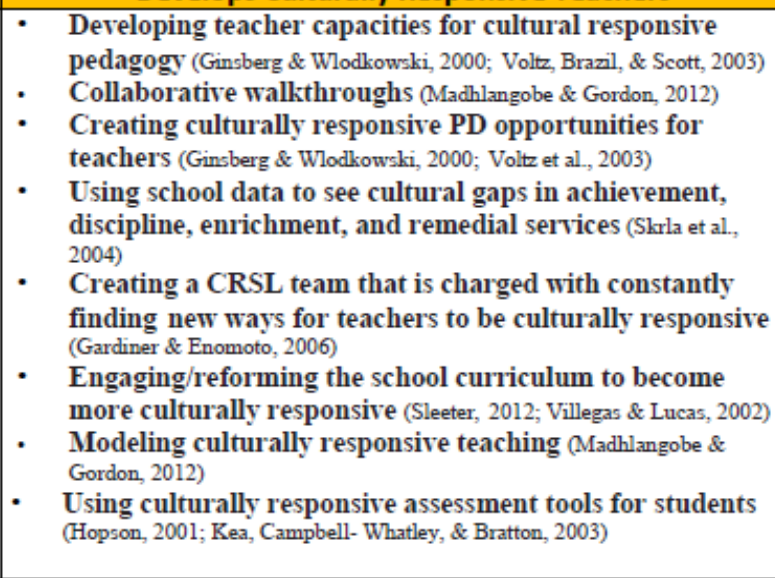 \\
\hline $\begin{array}{c}\text { Promotes Culturally Responsive/Inclusive School } \\
\text { Environment }\end{array}$ & \\
\hline 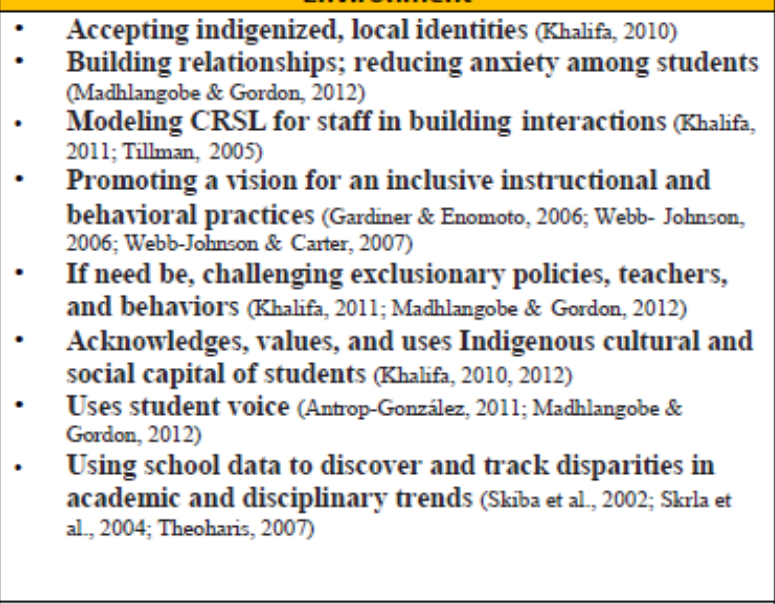 & 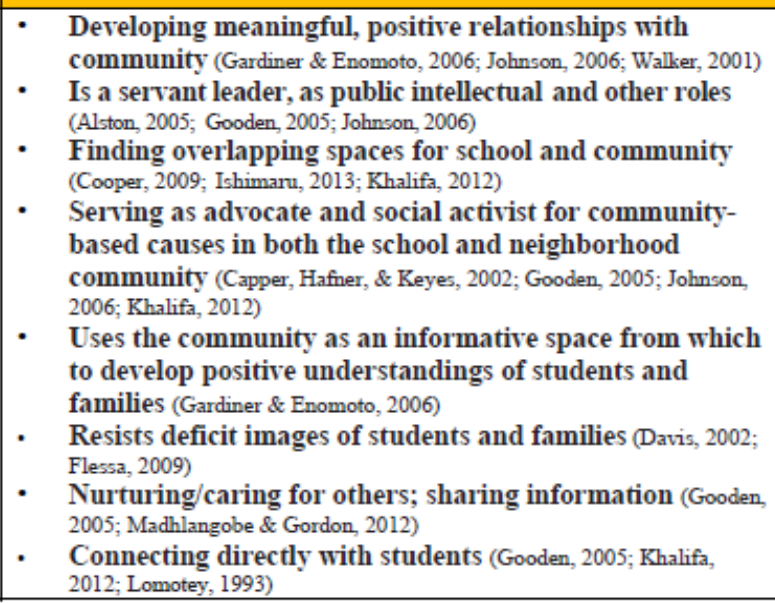 \\
\hline
\end{tabular}

Table 1. Culturally Responsive School Leadership Framework (Khalifa, Gooden, \& Davis, 2016).

\section{DATA COLLECTION}

We phoned Mr. Taylor to confirm his interest in participating, sent him a consent form, and scheduled our interviews. Two semistructured interviews were conducted by phone, lasting for $45-60$ minutes each. Questions ranged from inquiries about experiences that prepared him to lead the school, increasing community poverty, and navigating community resistance to using student performance data to inform instructional leadership and building community relationships. Document analysis was done using public domain student performance data from the state's department of education website. We also maintained field notes and included them in the analysis.

\section{DATA ANALYSIS}

Transcriptions of the descriptive interview data were coded and analyzed using NVivo 12th edition software to organize the analysis process, completing three rounds using a constant comparative method (Glaser \& Strauss, 1967; Merriam, 2001). Preliminary coding
New articles in this journal are licensed under a Creative Commons Attribution 4.0 United States License. Program and is cosponsored by the University of Pittsburgh Press.

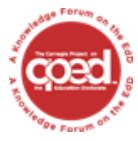

This journal is supported by the Carnegie Project on the Education Doctorate: A Knowledge Forum on the EdD (CPED) cpedinitiative.org 
produced deductive codes aligned with our conceptual framework, which consists of four strands:

- Critically self-reflects on leadership behaviors

- Develops culturally responsive teachers

- Promotes culturally responsive/inclusive school environment

- $\quad$ Engages students, parents, and indigenous contexts

\section{FINDINGS}

The data indicated that the superintendent-principal of this small rural school district demonstrated a range of beliefs and practices that supported improved student learning outcomes. His effective strategies are described in the four identified themes that follow, including nuanced, place-based challenges that are unique to rural contexts.

\section{Theme 1: Critically Self-Reflects on Leadership Behaviors}

The practices identified in the CRSL Framework surpass the identification of oppressive behaviors; they affirm and celebrate cultural practices, requiring leaders to learn about members of the communities in which they serve. Mr. Taylor consistently demonstrated a critical self-awareness, a practice that has significant influence on a school's cultural responsiveness. This opportunity for self-reflection in central to work as a transformative leader (Shields, 2010). His beliefs and practices are demonstrated in the quotes that follow:

We're learning together as a school; learning opens my eyes in a lot of ways about what's important to people - who are different than I am. How we approach a student that is acting out in class is different now. We stop and think, and are respectful to them, knowing that they may not know the answer and aren't just trying to disrupt the classroom. I'm reacting in a way that's different from how I might have reacted before. Lots of ways to support students is coming through our learning - and I think a lot about it, too.

He serves as an advocate as well as a social activist for communitybased causes in both the school and the neighborhood community. As he critically self-reflects on his leadership behaviors, he recognizes patterns that he now wants to change.

We're making a lot of opportunity for professional development. $70-75 \%$ of our students are Hispanic, and our staff doesn't reflect the same. We have a large Free and Reduced Lunch population, so we're doing a lot of education for ourselves. So for us to be culturally proficient, we need to make sure we have training to step outside of our comfort zone and say, "OK, this is how I perceive it; how are our students perceiving it? What is their world view, and how does it influence their outlook? How is it different from my way of thinking?" And that's all good.

Despite the reported pressures on most superintendent-principals to focus on managerial, operational, and fiscal issues (Curry, 2016), Mr. Taylor shared his beliefs and practices that have shifted the learning culture to support the improved math learning outcomes of students who have been traditionally marginalized. He challenges hegemonic epistemologies, and both acknowledges and values the indigenous cultural and social capital of the students and their families.
These beliefs and practices reframe him as an activist - a leader who grew up in very same school and district in which he serves as the superintendent-principal, who recognizes the critical need to improve the culturally responsive capacity of teachers and the school environment that has changed significantly since he grew up there. He shows his commitment to continuous learning about the cultural knowledge of their context.

\section{Theme 2: Promotes Culturally Responsive/Inclusive School Environment}

The literature indicates that school leaders must leverage resources to foster a learning environment that is both culturally responsive and inclusive (Dantley \& Tillman, 2006). The interview transcripts allude to Mr. Taylor's protection of indigenous student identities, those who have been traditionally marginalized at this school, as in most across the country. His beliefs and practices related to this strand are shown in the following quotes:

Our most recent professional development has been on trauma-informed care, and that has been eye opening. You know a student may have five things that happen to them that morning. And when they finally make it to school, if the first thing we do is jump on them, then we've just created the sixth thing that's going to completely destroy how their day goes and their ability to be available to learn.

He reduces anxiety among students, and challenges exclusionary or aggressive behaviors among the adults who work with students. He promotes a vision for inclusive instructional and behavioral practices, in the classroom and across the district.

It's helped us better understand where our students and their families are coming from. Because sometimes we do have different ideas of how we see things, and this has allowed us to really understand our students. It may not be that students are purposefully trying to be late; maybe there are some things going on in their life that make them late. What can we do to assist them with that?

\section{Theme 3: Develops Culturally Responsive Curricula and Teachers}

The majority of teachers in this country are white females (Sleeter, 2012), in stark contrast to the rapidly racially, culturally, linguistically, and socioeconomically diversifying portrait of American school students. It is incumbent upon the principal to develop a culturally responsive teaching culture, by modeling expectations, guiding the development of culturally responsive curricula, and providing on-going professional development. The leader learns to interrogate assumptions about race, class, and culture and their impact on student learning. Beliefs and practices that Mr. Taylor demonstrated aligned with this strand of the CRSL Framework are included in the quotes that follow:

We're all learning - and our teachers are becoming more culturally responsive, thanks to our PD. I encourage our staff if you need to go get PD, tell me when, where, how much, and we'll pay for it. We'll get you there. You can get that professional development you need that will better assist you. Because teachers have different needs, strengths, and they need to build on those as well. So we constantly encourage that. How can I get you what you need?

We've done a lot of training lately on ADD, Autism Spectrum Disorder, those kinds of trainings. I believe that what we need 
to do is have lots and lots of tools for our teachers' tool bags, so that's what I try to do. How can I increase your tools, so that you are able to deal with those situations?

We look at each student individually; that kind of approach puts a lot of accountability back on us as educators, because if Bobby doesn't have the skills he needs next year, we're accountable for that. We have to learn how to make sure that every one of our students has the skills they need; teachers are starting to feel the same way.

When you have a class of 15 , it is very, very easy to break that down when you get to the data and say, I know who needs what. And so when we have an achievement gap, we know who those 2, 3, or 4 students are who we need to increase their skills - and we teach to support them. We stay away from that 30,000 feet view and get down to the 3,000 foot individual student view. What does this student need and how are we gonna get him those skills? Individualized instruction, extra instruction, progress monitoring. What do we need to do to make sure this student has the skill when they leave us... to go to the next grade level, or their future, whatever it may be?

He understands the need to develop teacher capacity for culturally responsive pedagogy and supports them (and himself) with on-going professional development. He promotes a vision for an inclusive instructional and behavioral culture. As a "warm demander" (Bondy \& Ross, 2008), the superintendent-principal holds high academic expectations for district students while consistently showing caring support for them. This practice is in sharp contrast to a laser-sharp focus on the budget, discipline, and buses, as reported by many rural leaders who serve in this dual role (Curry, 2016). He is reforming the district curricula to become more culturally responsive and uses school data to see cultural gaps in achievement.

To meet their individual students' needs, our teachers bring in supplemental material to meet students' interests, their needs, their world view, and their ideas. How do they do that? They go find or make those individual supplemental materials to meet those diverse needs. What we've done is encouraged and supported our staff, through budgeting, by allowing them to purchase outside resources to meet differing individual needs in their classroom. If we can be very clear about the various needs of students and therefore the different methods we need, then I think we can teach in a way that will meet all students' needs. Is it easy? No. Do I think our teachers do a pretty good job of it? I really do.

Recently, we've been finding mental health and behavior specialist resources. Having those people who are able to meet the needs of some of the mental health and behavior issues that we are seeing currently in the community is critical.

\section{Theme 4: Engages Students and Families in Community Contexts}

The principal must demonstrate the ability to understand and address community-based issues, creating school spaces for traditionally marginalized student identities. Most of the students in this study come from families for whom this study context is indigenous, who identify as Chicano or Mestizo, rather than from a Native American ancestry. Mr. Taylor leans on the community as an informative space from which to develop positive understandings of students and their families (Gardiner \& Enomoto, 2006). He has made decisions that make the Great Bend School District seem like a caring community, designed to meet diversifying needs. He finds spaces that overlap between the school and the community. The quotes that follow here show how he engages students and families in community contexts:

Tardiness has been a major problem for a long time here. If a student is habitually tardy, for example, that seems to be a big one, we try to go beyond that they were tardy. We try to find out why they were tardy. How did we assist with that? Well, we bought washers and dryers for them to use here at the school. Now we can help a student with those things so they're on time to school, ready and committed to learn - and knowing that we care about them. Students have to meet their basic needs; we all do. If those needs aren't met, algebra becomes pretty unimportant. And so we try to make sure those basic needs are met - safety and food, and all those things are met. Then we go to the good teaching after that.

We use this strategy in our teachers' meetings all the time. One teacher will say, "I have a problem with this student, I'm having this issue. How can I really get feedback from our colleagues, how can I better meet the student's needs?" We talk about that as a school - a community. What do know about their family and their home life? What can we do to help? That awareness piece has been huge.

There are very different world views about life goals and opportunities, expectations, and family situations in our community now. How we overcome those - not overcome them, but how we assist with those so that every student is very, very successful is so important. It even shows with their grades - and they want to be here.

He resists deficit images of students and their families. By inviting the community to participate actively in important decisions, he has validated their role in the education of their students. He models acceptance and welcoming of indigenized, local identities, and describes himself as a servant leader.

I've been here a long time, and sometimes we all get in a rut. We start thinking that this is what we need to do, or this is what we've done. And what I've started to see is that there are definitely different needs among our students. We have to be very, very cognizant and open to those needs. The one size fits all approach will not work. And so that is what we've been really focusing on. I think it goes back to that understanding that not everybody is like me. Not everybody has been brought up in the same way, and that's not good or bad. I'm not saying that my way is better than anybody else's. I'm just saying everybody is brought up in a different way, and we all have different needs.

I try to follow more of a servant-leader model than a top-down leader and I believe in supporting professional development for all of us. I think that is so key - to give people the knowledge about current practices to meet our ever-changing population and their changing needs in the educational system.

Community-based advocacy leads to trust between the educational leader and members of the community they serve (Anderson, 2009). Mr. Taylor describes how he develops positive, meaningful relationships with the community.

We are such a small district that everybody's invited for our accountability committee - anybody can serve on it. And we invite people numerous times, please come serve. We usually, if we have anything that's even remotely interesting, we think it's going to be something the community really wants to talk about, we'll call a community meeting about it. You're talking $30,40,50$ people showing up, but we'll have it in the cafeteria, and invite folks to come give us their thoughts on it. We did this recently - we've been talking about a four day week. We're the only school in our area that still has a five day school 
week. So, we've been talking about that, we've had some community meetings on this, and people come in - they all know they're welcome and we want to hear what they have to say. And then we have six very active board members and they do a great job in the community. People talk to them and they'll pass along concerns or needs as they hear them as well.

Mr. Taylor uses the community as an informative space from which to develop positive understanding about their students and families.

I personally have had an opportunity to grow and be promoted from within this school and district. I went to school here, I did my student teaching here, became a teacher here, became a principal here, and now I'm the superintendent of this school district, as well. And so I've had an opportunity to grow, so I understand our values, our strengths, and the changing needs of our students in our community.

I really do have an open door policy as far as people can come see me at any time, they don't need to make an appointment. They can literally walk in almost any time to see me in my office. I'm at all the district events, and they're welcome to stop me there and tell me their concerns. I live right across from the school, believe it or not, so people also will stop by my house after hours to tell me if they have concerns about anything. Our community is really good. They're supportive of our students and our school. Our school is the hub of this community.

\section{DISCUSSION}

Few studies have examined the role of the rural superintendentprincipal, particularly related to the influence of that leader on student learning outcomes. Further, limited research has studied the influence of the rural superintendent-principal on learning outcomes of students whose identities have been traditionally marginalized. The Culturally Responsive School Leadership Framework (Khalifa, Gooden, \& Davis, 2016) has been applied in few rural research contexts. This study examined the beliefs and practices of a rural superintendent-principal who serves as the principal of the district's $\mathrm{K}-12$ schools, a coach, substitute teacher, district maintenance director, transportation director/bus driver, curriculum director, district superintendent, business manager, and district superintendent. This dual role is one of the most complex in education, one for which few rural leaders are ever adequately trained, and the one that has the highest attrition rate nationally (Curry, 2016). These findings contribute to the limited scholarship on the influence of the beliefs and practices of the superintendent-principal on the learning outcome trajectories of historically marginalized students.

Mr. Taylor reframes activism as leadership (Martin, William, Green, \& Smith, 2019). He leads for social change within his community, and "disrupts and transforms existing institutional arrangements" (Fine, 1994, p. 17)

\section{IMPLICATIONS FOR RESEARCH, PRACTICE, AND POLICY}

This work contributes to the limited body of research knowledge on rural educational leaders, particularly the superintendentprincipal. Our results showed an alignment between his beliefs and practices and student learning. It informs leadership preparation programs, as well as professional development options, about the need for contextually nuanced, culturally responsive leadership training for rural educational leaders to support the improved learning outcomes of traditionally marginalized rural students. Our study has implications for understanding the influence of a rural school leader's beliefs and practices on the successful learning outcomes of traditionally marginalized students. Students pursuing an educational doctorate degree may find this study helpful in addressing their research on the critical need for culturally responsive rural leaders.

While a principal is ultimately responsible for the success of every student in their school (Leithwood, Louis, Anderson, \& Wahlstrom 2004), there are significant contextual differences between leaders who serve in rural and non-rural settings. Identifying specific beliefs and practices used by the rural superintendentprincipal in the study school district now provides support for people who serve in that role, about which very little has been written. This study describes the superintendent-principal's beliefs and practices, aligned with indicators of the Culturally Responsive School Leadership Framework (Khalifa, 2018), with implications for rural K12 schools, for rural leadership preparation, for future research, and for policy. Rural educational leaders must learn to develop culturally responsive schools, disrupting the hegemonic interpretation of local reality and engaging diverse voices of students, their families, and community members. Seeking to understand funds of knowledge and the community cultural wealth (Kiyama et al, 2018; Moll et al, 2013; Yosso, 2005) of diversifying rural community members, rather than reproducing the power of competing narratives, will support a shared vision for systemic improvement throughout rural communities.

The recommendations that follow incorporate suggestions for future research related to policy, practice, and scholarship.

\section{Recommended Considerations for Future Research}

Future studies related to increased expectations for and support of traditionally marginalized students in rural schools will contribute to a clearer understanding of the impact of the educational leader on improving learning.

How can leadership preparation programs be redesigned to support the preparation of equitable rural school and district leaders, considering significant differences between their roles and responsibilities and those of their non-rural peers?

How can the role conflict inherent in the rural superintendent-principal role be minimized, with a shift away from an emphasis on managerial issues and toward improving student learning (for every student) through a culturally responsive leadership lens?

How can rural educational leaders collaborate through such loosely coupled structures as a networked improvement community to accelerate the improvement of leadership, teaching, and student learning outcomes, at little cost?

\section{Recommended Considerations for Practice}

Students pursuing the educational doctorate need to be able to demonstrate how their work impacts the field. Seldom does an 
aspiring school leader plan to become a superintendent-principal. If such an opportunity presents itself, however, that educational leader needs to understand the nuanced context of rural schools and districts. The beliefs and practices displayed by the subject of this study provide guidance for aspiring rural school and district leaders who are committed to equitable learning outcomes for every student.

How can leadership preparation programs design curriculum to be responsive to the rapidly changing needs of rural school leaders, particularly in light of increasing racial, cultural, linguistic, and economic diversification of rural communities?

What innovative professional development structures can inform both practitioners and researchers in the process of improving student learning in rural contexts?

\section{Recommended Considerations for Policy}

Policy recommendations should be designed to encompass systematic training, including district and school leadership teams comprised of administrators, teachers, students, and members of the community.

How can local, state, and national policy makers support low-cost, innovative practice-research partnerships in the preparation and mentoring of culturally responsive rural educational leaders?

\section{Limitations}

Flyvbjerg (2006) stresses that the ability of a multiple case study to have generalizable findings is overestimated. In fact, he suggests that the impact of a single case study is underrated. While we did not set out to generate theory from this study, we suggest that there are important leadership lessons that can be learned by studying this case. The fact that there is only one leader studied establishes limitations, including those related to his gender, race, sexual preference, socioeconomic status, and native language. Additionally, we set relatively high enrollment parameters for a school district to qualify for this study. Adjusting them to include more contexts would contribute to the findings, as would the expansion of the context to additional states and regions across the country.

\section{Scholarly Significance of the Study}

This study advances our knowledge of the foundational beliefs and practices of rural educational leaders that improve equitable learning for every student. These impactful beliefs and practices should be central to rural leadership preparation and serve as the bedrock of professional development. What educational leaders do and believe has especially strong impact when aligned with what teachers do collaboratively to improve student learning (Goddard, Goddard \& Tschannen-Moran, 2007). Evidence of Mr. Taylor's alignment to behaviors from the CRSL Framework (Khalifa, Gooden, \& Davis, 2018) provides the reader with linkage to understand how he shaped the culture of his rural school district. These findings will be useful to inform the preparation of culturally responsive rural educational leaders, as well as to advise leadership programs to prepare leaders to strategically lead an aligned, culturally responsive system of improvement for teaching and learning that advances learning outcomes for every student. Rural boards of education can learn about place-based nuances to support every student, as well as issues related to role conflict within the dual role from this study.

\section{REFERENCES}

Anderson, G. L. (2009). Advocacy leadership: Toward a post-reform agenda in education. Routledge.

Balkar, B. (2015). Defining an empowering school culture (ESC): Teacher perceptions. Issues in Educational Research, 25(3), 205.

Barrett, N., Cowen, J., Toma, E., \& Troske, S. (2015). Working with what they have: Professional development as a reform strategy in rural schools. Journal of Research in Rural Education (Online), 30(10), 1.

Bernhardt, V. (2013). Data analysis for continuous school improvement. New York, NY: Routledge.

Bondy, E., \& Ross, D. D. (2008). The teacher as warm demander. Educational Leadership, 66(1), 54-58.

Brayboy, B. M. J., Castagno, A. E., \& Maughan, E. (2007). Equality and justice for all? Examining race in education scholarship. Review of Research in Education, 31(1), 159-194

Curry, M. C. (2016). Role and responsibility priorities of the superintendent/principal as perceived by board presidents, teachers' union presidents, and superintendent/principals. ProQuest Dissertations \& Theses Global; Social Science Premium Collection. (1860892779).

Dantley, M. E., \& Tillman, L. C. (2006). Social justice and moral transformative leadership. In C. Marshall \& M. Oliva (Eds.), Leadership for social justice: Making revolutions in education (pp. 16-30). Boston, MA: Allyn \& Bacon.

Darling-Hammond, L. (2010). Performance counts: Assessment systems that support high-quality learning. Washington, D.C.: Council of Chief State School Officers.

Fine, M. (1994). Working the hyphens. Handbook of qualitative research. Thousand Oaks, CA: Sage.

Flyvbjerg, B. (2006). Five misunderstandings about case-study research. Qualitative Inquiry,(12)2, 219-245.

Fusarelli, B. C., \& Militello, M. (2012). Racing to the top with leaders in rural, high poverty schools. Planning and Changing, 43(1), 46-56.

Galloway, M. K., \& Ishimaru, A. M. (2015). Radical recentering: Equity in educational leadership standards. Educational Administration Quarterly, 51(3), 372-408.

Gardiner, M. E., \& Enomoto, E. K. (2006). Urban school principals and their role as multicultural leaders. Urban Education, 41(6), 560-584.

Geverdt, D. (2015). Education demographic and geographic estimates program (EDGE): Locale boundaries user's manual (NCES 2016-012). U.S. Department of Education. Washington, DC: National Center for Education Statistics.

Glaser, B. G., \& Strauss, A. L. (1967). The discovery of grounded theory. Chicago: Aldine.

Goddard, Y. L., Goddard, R. D., \& Tschannen-Moran, M. (2007). A theoretical and empirical investigation of teacher collaboration for school improvement and student achievement in public elementary schools. Teachers College Record, 109(4), 877-896.

Hallinger, P., Heck, R. H., \& Murphy, J. (2014). Teacher evaluation and school improvement: An analysis of the evidence. Educational Assessment, Evaluation and Accountability, 26(1), 5-28

Harris, A. (2013). School improvement: What's in it for schools? New York, NY: Routledge.

Hesbol, D. G. (2005). The role understanding and perceptions of the superintendent/principal in small rural Illinois schools. University of Illinois at Urbana-Champaign.

Hesbol, K. A. (2020, Winter). The rural innovative school leadership networked improvement community: Background and future of a NIC in practice. In J. Hanley (Ed.), Point/counterpoint: How networked improvement communities work to support rural education. UCEA Review, 60(4), 20 23.

Jacobs, J., Boardman, A., Potvin, A., \& Wang, C. (2018). Understanding teacher resistance to instructional coaching. Professional Development in Education, 44(5), 690-703.

Khalifa, M.A., Gooden, M.A., \& Davis, J.E. (2016). Culturally responsive schoo leadership: A synthesis of the literature. Review of Educational Research, 86(4), 1272-1311. 
Khalifa, M. A. (2018). Culturally responsive school leadership. Cambridge, MA: Harvard Education Press.

Khalifa, M. A., Gooden, M. A., \& Davis, J. E. (2018). Culturally responsive school leadership framework. Bloomington, MN: University of Minnesota Organizational Leadership, Policy, \& Development.

Kiyama, J. M., Rios-Aguilar, C., \& Sarubbi, M. (2018). A review of existing research on funds of knowledge and the forms of capital. In J.M. Kiyama, \& C. Rios-Aguilar (Eds.), Funds of knowledge in higher education: Honoring students' cultural experiences and resources as strengths (pp. 25-47). New York, NY: Routledge.

Ladson-Billings, G. (2006). From the achievement gap to the education debt: Understanding achievement in US schools. Educational Researcher, 35(7), 3-12.

Leithwood, K., Louis, K.S., Anderson, S., \& Wahlstrom, K. (2004). How leadership influences student learning. New York, NY: Wallace Foundation.

Lincoln Y., \& Guba, E. (1985). Naturalistic inquiry. Newbury Park: Sage Publications.

Martin, G. L., Williams, B. M., Green, B., \& Smith, M. J. (2019). Reframing activism as leadership. New directions for student leadership, (161), 924.

McHenry-Sorber, E., \& Provinzano, K. (2017). Confronting rapid change: Exploring the practices of educational leaders in a rural boomtown. Leadership and Policy in Schools, 16(4), 602-628.

Merriam, S. B. (2001). Qualitative research and case study applications in education. San Francisco: Jossey-Bass.

Moll, L. C., Soto-Santiago, S. L., \& Schwartz, L. (2013). Funds of knowledge in changing communities. In K. Hall, T. Cremin, B. Comber, \& L. Moll (Eds.), International Handbook of Research on Children's Literacy, Learning, and Culture (pp. 172-183). John Wiley and Sons. https://doi.org/10.1002/9781118323342.ch13

Perry, J. A. (2018). Adapted from the October 2017 convening opening address: CPED beyond 10 years. Impacting Education: Journal on Transforming Professional Practice, 3(1).

Pohl, K. (2017, August). Minority populations driving county growth in the rural west. Rural west insights series. Bozeman, MT: Headwaters Economics.

Pounder, D., Reitzug, U., \& Young, M. (2002). Preparing school leaders for school improvement, social justice, and community. Yearbook of the National Society for the Study of Education, 101(1), 261-288.

Salazar, P. S. (2007). The professional development needs of rural high school principals: A seven-state study. The Rural Educator 28(3), 20-27.

Shields, C. M. (2010). Transformative leadership: Working for equity in diverse contexts. Educational Administration Quarterly, 46(4), 558-589.

Showalter, D., Hartman, S.., Johnson, J., \& Klein, B. (2019). Why rural matters 2018-2019: The time is now. Washington, D.C.: Rural School and Community Trust.

Shulman, L. S. (2005). Signature pedagogies in the professions. Daedalus, 134(3), 52-59.

Skrla, L., McKenzie, K. B., \& Scheurich, J. J. (2009). Using equity audits to create equitable and excellent schools. Thousand Oaks, CA: Corwin Press.

Sleeter, C. E. (2012). Confronting the marginalization of culturally responsive pedagogy. Urban Education, 47(3), 562-584.

Stake, R. (1995). The art of case study research. Thousand Oaks, CA: Sage Publications.

Theoharis, G., \& Causton-Theoharis, J. (2008). Creating inclusive schools for all students. School Administrator, 65(8), 24-25.

Valiandes, S. (2015). Evaluating the impact of differentiated instruction on literacy and reading in mixed ability classrooms: Quality and equity dimensions of education effectiveness. Studies in Educational Evaluation, 45, 17-26.

Yin, R. K. (2017). Case study research and applications: Design and methods $\left(7^{\text {th }}\right.$ ed.). Thousand Oaks, CA: Sage Publications.

Yosso, T. J. (2005). Whose culture has capital? A critical race theory discussion of community cultural wealth. Race, Ethnicity, and Education, 8(1), 69-91.

Zhang, Y. (2008). Some perspectives from rural school districts on the No Child Left Behind Act. Washington, DC: Center on Education Policy. 
c) (i) New articles in this journal are licensed under a Creative Commons Attribution 4.0 United States License.

Program and is cosponsored by the University of Pittsburgh Press.

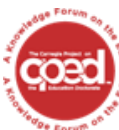

This journal is supported by the Carnegie Project on the Education Doctorate: A Knowledge Forum on the EdD (CPED) cpedinitiative.org

impactinged.pitt.edu

Vol.5, No. 2 (2020)

ISSN 2472-5889 (online) DOI 10.5195/ie.2020.134 